\title{
Bacteria occurring in onion (Allium cepa L.) foliage in Puerto Rico',
}

\author{
Juan Calle-Bellido ${ }^{3}$ Lydia I. Rivera-Vargas ${ }^{4}$, Myrna Alameda ${ }^{4}$ \\ and Irma Cabrera ${ }^{5}$
}

J. Agric. Univ. P.R. 96(3-4):199-219 (2012)

\begin{abstract}
Bacteria associated with foliar symptoms of onion (Allium cepa L.) were examined in the southern region of Puerto Rico from January through April 2004. Different symptoms were observed in onion foliage of cultivars 'Mercedes' and 'Excalibur' at Juana Díaz and Santa Isabel, Puerto Rico. Ellipsoidal sunken lesions with soft rot and disruption of tissue were the most common symptoms observed in onion foliage in field conditions. From a total of 39 bacterial strains isolated from diverse symptoms in onion foliage, $38 \%$ were isolated from soft rotting lesions. Ninety-two percent of the bacteria isolated from onion foliage was Gram negative. Pantoea spp. with $25 \%$, was the most frequently isolated genus, followed by Pasteurella spp. and Serratia rubidae with $10 \%$ each. Fiftysix percent of the strains held plant pathogenic potential; these strains belong to the genera Acidovorax sp., Burkholderia sp., Clavibacter sp., Curtobacterium sp., Enterobacter sp., Pantoea spp., Pseudomonas spp., and Xanthomonas spp. Pathogenicity tests showed that seven out of eight tested bacterial strains evaluated under field conditions caused symptoms in onion foliage for both cultivars. Acidovorax avenae subsp. citrulli, Burkholderia glumae, Pantoea agglomerans, P. dispersa, Pseudomonas sp., Xanthomonas sp., and Xanthomonas-like sp. were pathogenic to leaf tissues. Clavibacter michiganensis was not pathogenic to leaf tissues. Other bacteria identified as associated with onion leaf tissue were Curtobacterium flaccumfaciens, Cytophaga sp., Enterobacter cloacae, Flavimonas oryzihabitans, Mannheimia haemolytica, Pantoea stewartii, Pasteurella anatis, P. bettyae, P. langaaensis, Photobacterium damselae, Pseudomonas syringae pv. aptata, Rhizobium radiobacter, Serratia rubidae, Sphingobacterium spiritivorum, Sphingomonas sanguinis, and an unknown strain. This paper is the first survey of bacteria associated with onion foliage in Puerto Rico. The role of nonphytopathogenic bacteria associated with the life cycle of onion under field conditions remains unknown.
\end{abstract}

${ }^{1}$ Manuscript submitted to Editorial Board 29 March 2012.

${ }^{2}$ This research was supported by an USDA TSTAR-97 Grant.

${ }^{3}$ Former Graduate Student, Dept. of Agronomy and Soils, P.O. Box 9000, University of Puerto Rico, Mayagüez, P.R. 00681-9030.

${ }^{4}$ Professor, Dept. of Crops and Agro-Environmental Sciences, P.O. Box 9000, University of Puerto Rico, Mayagüez, P.R. 00681-9030. e-mail: lydiai.rivera@upr.edu

${ }^{5}$ Professor, Dept. of Crops and Agro-Environmental Sciences, HC-04 Box 7115, Agricultural Experiment Station, Juana Díaz, P.R. 00795-9998. 
Key words: bacteria, onion, Allium cepa, Acidovorax, Burkholderia, Clavibacter, Pantoea, Pseudomonas, Xanthomonas

\section{RESUMEN}

Bacterias que ocurren en el follaje de cebolla (Allium cepa L.) en

Puerto Rico

Se examinaron las bacterias asociadas a síntomas foliares de cebolla (Allium cepa L.) en predios de la región sur de Puerto Rico durante los meses de enero a abril de 2004. Se observaron diferentes síntomas en el follaje de los cultivares 'Mercedes' y 'Excalibur' en Juana Díaz y Santa Isabel, Puerto Rico. El síntoma más comúnmente observado en el follaje de cebolla en condiciones de campo fue una lesión elipsoidal hundida con pudrición blanda y destrucción del tejido. De un total de 39 cepas de bacterias aisladas de las lesiones del follaje, $38 \%$ fueron aisladas de lesiones con pudriciones blandas. Noventa y dos por ciento de las bacterias aisladas fueron Gram negativas. Pantoea spp., con un $23 \%$, fue el género más frecuente, seguido por Pasteurella spp. y Serratia rubidae con $10 \%$ cada una. Cincuenta y seis por ciento de las cepas identificadas poseen potencial fitopatológico; estas pertenecen a los géneros Acidovorax sp., Burkholderia sp., Clavibacter sp., Curtobacterium sp., Enterobactaer sp., Pantoea spp., Pseudomonas spp. y Xanthomonas spp. Las pruebas de patogenicidad demostraron que siete de ocho cepas examinadas en el campo causaron síntomas en el follaje de cebolla en ambos cultivares. Acidovorax avenae subsp. citrulli, Burkholderia glumae, Pantoea agglomerans, P. dispersa, Pseudomonas sp., Xanthomonas sp. y una cepa parecida a Xanthomonas sp. fueron patogénicas al tejido foliar. Clavibacter michiganensis no mostró patogenicidad. Otras bacterias identificadas asociadas al tejido del follaje de cebolla fueron Curtobacterium flaccumfaciens, Cytophaga sp., Enterobacter cloacae, Flavimonas oryzihabitans, Mannheimia haemolytica, Pantoea stewartii, Pasteurella anatis, $P$. bettyae, P. langaaensis, Photobacterium damselae, Pseudomonas syringae pv. aptata, Rhizobium radiobacter, Serratia rubidae, Sphingobacterium spiritivorum, Sphingomonas sanguinis, y una cepa desconocida. Este es el primer catastro sobre la diversidad bacteriana asociada al follaje de cebolla en Puerto Rico. Se desconoce el rol de las bacterias no fitopatógenas asociadas al ciclo de vida de la cebolla bajo condiciones de campo.

Palabras clave: bacteria, cebolla, Allium cepa, Acidovorax, Burkholderia, Clavibacter, Pantoea, Pseudomonas, Xanthomonas

\section{INTRODUCTION}

Worldwide, onions are a very important commodity. Total annual bulb production in 2009 was estimated at 73 million metric tons (FAOSTAT, 2010). In Puerto Rico, the estimated value of the onion crop for fiscal year 2009-2010 was $\$ 3.8$ million, showing an increase of $\$ 2.1$ million in production from previous fiscal year (Department of Agriculture of Puerto Rico, 2010). Diseases constrain onion production by affecting plant development and bulb quality. In general, 
bulbs stimulate bacterial and fungal development, some of which can invade the root cortex and act as pathogens or saprophytes (Schwartz and Mohan, 1995). Few bacterial pathogens have been reported causing foliar diseases in onion (Allium cepa L.). Symptoms such as leaf blight caused by Xanthomonas axonopodis pathovar alli (syn. $X$. campestris); premature leaf dieback caused by Enterobacter cloacae; leaf streak caused by Pseudomonas viridiflava; leaf necrosis caused by three different species, Pantoea agglomerans [syn. Erwinia herbicola (Ewing and Fife)], Pseudomonas marginalis (Brown) and Pseudomonas syringae pv. syringae (van Hall); center rot of onion caused by Pantoea ananatis (Serrano) Mergaret; and water soaked lesions caused by Erwinia rhapontici (Millar) Burkholder and Pseudomonas marginalis pv. marginalis (Brown) Stevens have been described elsewhere (Gent et al., 2005; Gitaitis et al., 2003; Schroeder et al., 2009; Schwartz and Mohan, 1995; Serfontein, 2001).

In subtropical and tropical areas, Xanthomonas axonopodis pathovar alli (syn. Xanthomonas campestris) is an important disease causing onion leaf blight (Schwartz and Gent, 2005; O'Garro and Paulraj, 1997). The disease has been reported in Barbados, Brazil, Cuba and Hawaii (Álvarez et al., 1978; O'Garro and Paulraj, 1997; Neto et al., 1987). Because of the increase of onion production in the Caribbean, bacterial blight might represent a threat to Puerto Rico's onion production. Another important foliar necrotic pathogen is $P$. viridiflava, which also affects bulbs in the field and during post harvest (Schwartz and Mohan, 1995). Pantoea agglomerans (=Erwinia herbicola) has been reported in South Africa as causing rapid necrosis of seed stalk leading to the weakening and collapse of the heads (Schwartz and Mohan, 1995). In New Zealand, $P$. marginalis caused leaf necrosis and rot of the entire plant. This disease initially caused small water-soaked lesions that turned brown, rotting the entire plant. In Japan, $E$. rhapontici and $P$. marginalis pv. marginalis cause small water-soaked lesions that enlarge along the veins to leaf sheaths (Snowdon, 2002). Evidence shows that $P$. ananatis causes center rot and white streaks with water-soaked margins on onion leaves; it is transmitted by the thrips, Frankliniella fusca (Gitaitis et al., 2003).

In Puerto Rico, there have been no thorough studies of bacteria occurring in onion foliage. Our objective was to study bacterial diversity associated with onion foliage symptoms, emphasizing phytopatogenic species. This information will provide better knowledge of diversity and agricultural importance for further established control practices that might reduce disease losses in the field. 


\section{MATERIALS AND METHODS}

Description of commercial onion fields: Commercial onion fields were located at road PR-1, Bo. Jauca Sector Destino in Santa Isabel, in the southern region of Puerto Rico. Onion plot size ranged from 2.9 to 3.7 hectares. Four plots were randomly sampled, two plots of each cultivar: 'Excalibur' (Sunseeds®) or 'Mercedes' (Seminis®) ${ }^{6}$. Onion seeds $(3.5 \mathrm{~kg} / \mathrm{ha})$ were mechanically planted at approximately $12.5-\mathrm{mm}$ depth on raised beds of $15 \mathrm{~cm}$ to $20 \mathrm{~cm}$ above soil level. Four onion rows of approximately $5-\mathrm{cm}$ width were planted per bed. Onion plants were separated from each other by $7.6 \mathrm{~cm}$. Herbicides such as oxyfluorfen $(0.14 \mathrm{~kg}$ ai $/ \mathrm{ha})$ and fluazitopP-butyl ( 12 to $18 \mathrm{~mL}$ in $93 \mathrm{~m}^{2}$ ) were applied when plants reached a trifoliate stage. Insecticides such as avermectin $(237 \mathrm{~mL} / 379 \mathrm{~L})$ and cypermethrin $(14 \mathrm{~mL} / 100 \mathrm{~L})$ were applied to control thrips or whiteflies, respectively. Iprodione was applied to control fungal pathogens $(0.85 \mathrm{~kg} /$ hectare $)$.

Isolation of foliar bacteria: A survey was conducted during onion growing season from January through April 2004 on commercial onion fields. The survey consisted of eight samplings at 15-day intervals. Onion leaves showing bacterial symptoms were collected at random from onion cultivars 'Mercedes' and 'Excalibur'. Symptoms included ellipsoidal sunken lesions with soft rot and disrupted tissue; round soft rot lesions; small white pustules; wide chlorotic lesions; dry wide white lesions; sunken chlorotic lesions causing strangling of the leaf; and chlorotic spots (Figure 1). Sections of leaf tissue $(4 \mathrm{~mm})$ showing symptoms were surface disinfested with $70 \%$ ethyl alcohol and $0.05 \%$ sodium hypochlorite, then rinsed four times with de-ionized sterile distilled water ( 1 min each). Leaf sections from margins of lesions were macerated in de-ionized sterile distilled water and streaked onto Tryptic Soy Agar (TSA, DIFCO). Plates were incubated at $26^{\circ} \mathrm{C}$ and examined after $24 \mathrm{~h}$. Bacterial colonies were randomly selected, purified, and transferred to a TSA slant. Pure cultures were kept at $4^{\circ} \mathrm{C}$.

Bacterial characterization: Colony morphology and Gram stain were examined for each bacterial strain. Endospore staining with malachite green (5\%) and safranin $(0.5 \%)$ for Gram positive bacteria were performed (Schaad et al., 2001). Additional tests were

\footnotetext{
${ }^{6}$ Company or trade names in this publication are used only to provide specific information. Mention of a company or trade name does not constitute a warranty of equipment or materials by the Agricultural Experiment Station of the University of Puerto Rico, nor is this mention a statement of preference over other equipment or materials.
} 


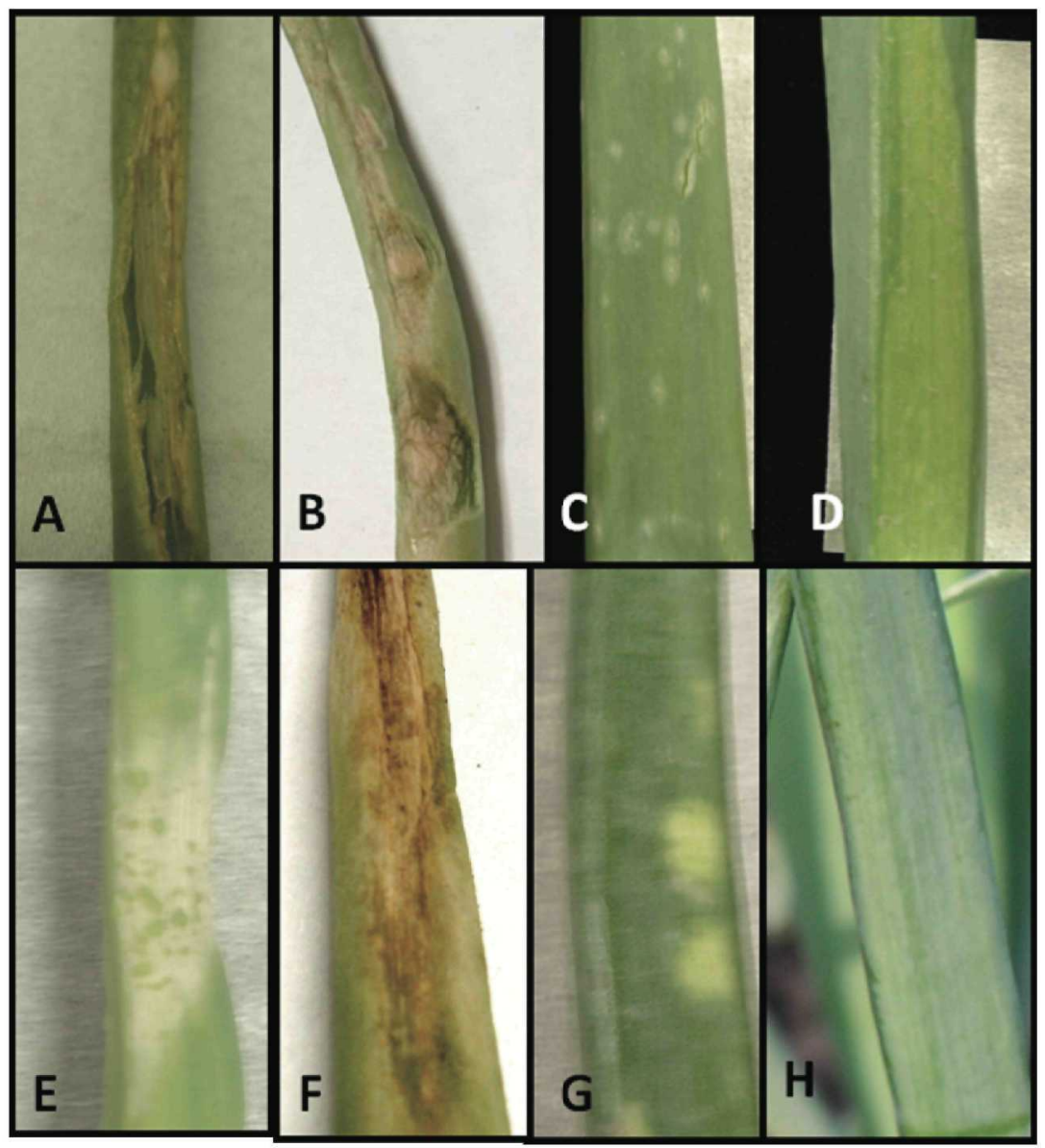

Figure 1. Symptoms observed in the field on onion foliage: A. Ellipsoidal sunken lesions with soft rot with disrupted tissue; B. Round soft rot lesions; C. Small white pustules; D. Wide chlorotic lesions; E. Dry wide white lesions; F. Sunken chlorotic lesions causing strangling of the leaf; $\mathrm{G}$. Chlorotic spots; and $\mathrm{H}$. Healthy onion leaves.

performed to determine the proper setup Biolog protocol for GNENT (enteric) and GN-NENT (non-enteric) Gram negative strains and hydrogen sulfide production. Two reaction colors were examined: yellow color or acidic reaction developed in the slant and bottom of the test tube, indicating the fermentation of dextrose, lactose and/or sucrose; and red color or alkaline reaction in the slant and bottom, indicating that the bacteria does not ferment sugars. Hy- 
drogen sulfide production results in a black precipitate in the bottom of the tube. Gas production is indicated by splitting and cracking of the medium.

BIOLOG@: Gram negative colonies were cultured in TSA for $24 \mathrm{~h}$ at $26^{\circ} \mathrm{C}$. Bacterial growth was transferred with a cotton swab previously dipped into $20 \mathrm{ml}$ of GN/GP inoculating fluid tubes (BIOLOG@ BL-72101) supplemented with three drops of sodium thioglycolate $(7.66 \%)$ (BIOLOG® BL-73011). Bacterial cell suspension readings were done with a spectrophotometer (Spectronic-21 Milton Roy-Company, USA) at $590 \mathrm{~nm}$ to establish turbidity range of $61 \%$ or $52 \%$ transmittance for enteric and non enteric bacteria, respectively. One hundred fifty microliters of bacterial suspension was pippetted to each well of GN2 microplates and incubated at $30^{\circ} \mathrm{C}$. Microplates readings were peformed at 4 to $6 \mathrm{~h}$ and at 18 to $24 \mathrm{~h}$ after incubation by using a BIOLOG® MicroStation System (4.1 version). Results were compared using a BIOLOG® data base for bacterial strain identification (Bochner, 1989).

Gram positive endospore forming bacteria were grown in BIOLOG® Universal Growth Media (BUGM) with maltose solution $(0.25 \%)$, and swabbed with sodium thioglycolate solution (eight drops of sodium thioglycolate into $3 \mathrm{~mL}$ distilled sterile water). A thin film of the sodium thioglycolate solution was spread across the surface of agar media (BUGM) until dried. After $24 \mathrm{~h}$ of incubation at $30^{\circ} \mathrm{C}$ bacterial colonies were transferred to fresh inoculating fluid tubes supplemented with three drops of sodium thioglycolate, as recommended for the GP microplate standard method (BIOLOG®, Inc), and transmittance was adjusted to $28 \%$. Afterward, each well of the GP2 microplate was inoculated with $150 \mu \mathrm{l}$ of bacterial suspension. Microplates were incubated at $30^{\circ} \mathrm{C}$, and readings were made as previously described. Gram positive strains that did not form endospores were incubated in BUGM at $30^{\circ} \mathrm{C}$ for $24 \mathrm{~h}$, transmittance being adjusted to $20 \%$.

Pathogenicity tests under field conditions: Pathogenicity tests were conducted at the University of Puerto Rico, Agricultural Experiment Station, Juana Díaz. The experimental design covered four blocks each of approximately 0.04 hectares. Each experimental block contained four plots of $30 \mathrm{~m}^{2}$. Over all, sixteen $30 \mathrm{~m}^{2}$ plots were planted with a manual seeder with onion cultivars 'Excalibur' (Sunseeds®) or 'Mercedes' (Seminis $\left.{ }^{\circledR}\right)$. Seeds were planted approximately $1 \mathrm{~cm}$ deep on beds raised $15 \mathrm{~cm}$ above soil level. Each plot measured $7 \mathrm{~m}$ long by $1 \mathrm{~m}$ wide and contained four onion rows. Each onion row was separated from the other by $18 \mathrm{~cm}$. Plants were separated from each other by $5 \mathrm{~cm}$. Prior to seed planting, herbicides 
such as fluazitop-p-butyl and oxyflourfen were applied. Insecticides such as avermectin and cypermethrin were applied after the second and sixth week of planting to control thrips or whiteflies, respectively. Iprodione was applied to control fungal pathogens.

Fifty-two-day-old onion plants were used for pathogenicity tests. Before inoculation, leaves were superficially disinfested with $70 \%$ ethyl alcohol, and rinsed with sterile de-ionized distilled water; four sterile pins were used to puncture the surface. Using a cotton swab, leaves were inoculated with $10^{9} \mathrm{cfu} / \mathrm{ml}$ of a bacterial suspension prepared in phosphate buffer (pH 7.2) (Gent et al., 2005). Bacteria were obtained from a $24 \mathrm{~h}$-old colony grown in TSA incubated at $26^{\circ} \mathrm{C}$. Identified bacterial strains of Acidovorax avenae subsp. citrulli, Burkholderia glumae, Clavibacter michiganensis, Pantoea agglomerans, $P$. dispersa, Pseudomonas sp., Xanthomonas sp. and a Xanthomonas-like strain were inoculated onto healthy onion leaves. Four plants from each onion cultivar ('Excalibur' or 'Mercedes') were inoculated per each bacterial strain; trials were replicated. Control plants were treated with phosphate buffer only. In the field, after $72 \mathrm{~h}$ of inoculation, evolution of symptoms was examined daily for a week. Leaves were removed from plants and bacteria were reisolated to complete Koch postulates, by using methods previously described.

Temperature, precipitation and relative humidity data were collected at a meteorological station located at UPR-Agricultural Experiment Station, Juana Díaz, Puerto Rico. Precipitation and temperature data were taken with Land Surface (N18 $01^{\prime} 58.2^{\prime \prime} / \mathrm{W} 66^{\circ}$ 31' 53.2") and Weskler (N 18 01.584' W 066 31. 531') instruments, respectively, of the National Climatic Data Center, United States Weather Bureau.

\section{RESULTS}

\section{Bacteria isolated from onion foliage}

Our study exposed the presence of a diverse bacterial population in onion foliar tissues of field plots located in the southern region of Puerto Rico. Thirty-nine bacterial strains belonging to 17 different genera were isolated from previously described symptoms observed in the field (Figure 1; Table 1). Table 1 presents details of bacterial strain identification, field location, onion cultivar, lesion type from which bacterial species was isolated and a possible source of origin based on literature.

Ninety-two percent of the bacterial strains isolated from onion foliage were Gram negative bacilli, predominantly of the Enterobacteria- 
ceae family. These were Enterobacter cloacae, Pantoea agglomerans, P. dispersa, P. sterwartii, and Serratia rubidae (Table 1). Pantoea spp. was the most frequent genus isolated from onion foliage, with $25 \%$, followed by Pasteurella spp. and Serratia with 10\% each (Figure 2). Eight percent of the bacterial strains were Gram positive coryneform bacteria that included two phytopathogenic species Curtobacterium flaccumfaciens and Clavibacter michiganensis. None of these form endospores. Fifty-six percent of the strains hold plant pathogenic potential belonging to the genera Acidovorax sp., Burkholderia sp., Clavibacter sp., Curtobacterium sp., Enterobacter sp., Pantoea spp., Pseudomonas spp., and Xanthomonas spp. Other bacterial species identified associated with onion leaf tissue were Cytophaga sp., Flavimonas oryzihabitans, Mannheimia haemolytica, Pasteurella anatis, $P$. bettyae, $P$. langaaensis, Photobacterium damselae, Pseudomonas syringae pathovar aptata, Rhizobium radiobacter, Serratia rubidae, Sphingobacterium spiritivorum, Sphingomonas sanguinis, and an unknown strain.

\section{Relation of bacterial species with foliar symptoms observed in the field}

Ellipsoidal sunken lesions with soft rot and disrupted tissue were the most common symptom observed in onion foliage in the field (Figure 1A). This was the only symptom observed at experimental plots as opposed to commercial plots, which showed a wide variety of symptoms such as round soft rot lesions, small white pustules, wide chlorotic lesions, dry wide white lesions, sunken chlorotic lesions causing strangling of the leaf and chlorotic spots (Figure 1). Sixteen different bacterial strains were isolated from commercial plots whereas nine were from experimental plots located at Santa Isabel and Juana Díaz, Puerto Rico, respectively. Pantoea dispersa was the only species that occurred at both locations (Table 1). Six bacterial species were isolated from both onion cultivars evaluated ('Mercedes' and 'Excalibur'). These were Curtobacterium flaccumfaciens, Pantoea agglomerans, $P$. dispersa, Pasteurella langaaensis, Serratia rubidae and Sphingomonas sanguinis. Five and twelve bacterial strains were isolated only from onion 'Excalibur' or 'Mercedes', respectively (Table 1). All Gram positive bacteria were isolated from commercial plots (Table 1).

Thirty-eight percent of bacterial strains were isolated from soft rot lesions, $28 \%$ from small white pustules, and $15 \%$ from wide chlorotic lesions (Figures $1 \mathrm{~A}, \mathrm{~B}, \mathrm{C}$ and D). Nine bacterial species were isolated from ellipsoidal sunken lesions with soft rot and disrupted tissue (Figure 1A). These were Acidovorax avenae subsp. citrulli, $B$. glumae, E. cloacae, $F$. oryzihabitans, $P$. dispersa, $P$. damselae, $P$. sy- 
TABLE 1. Bacterial strains isolated from onion (Allium cepa L.) foliar lesions in commercial and experimental field plots located at Juana Diaz and Santa Isabel, Puerto Rico.

\begin{tabular}{|c|c|c|c|c|c|c|}
\hline Bacterial Identification $^{1}$ & Location $^{2}$ & $\mathbf{C V}^{3}$ & Lesion type & $\begin{array}{l}\text { Gram } \\
\text { Stain }\end{array}$ & Possible Source $^{4}$ & References \\
\hline Acidovorax avenae subsp. citrulli (1) & JD & M & $\begin{array}{l}\text { Ellipsoidal sunken } \\
\text { lesion with soft rot } \\
\text { and disruption of } \\
\text { tissue }\end{array}$ & $(-)$ & $\begin{array}{l}\text { Plant pathogen: } \\
\text { cucurbit fruit rot, } \\
\text { especially in honey- } \\
\text { dew and fruit blotch } \\
\text { in watermelons. }\end{array}$ & $\begin{array}{l}\text { Isakeit et al., } \\
\text { 1997; Somodi } \\
\text { et al., } 1991\end{array}$ \\
\hline Burkholderia glumae (1) & JD & M & $\begin{array}{l}\text { Ellipsoidal sunken } \\
\text { lesion with soft rot } \\
\text { and disruption of } \\
\text { tissue }\end{array}$ & $(-)$ & $\begin{array}{l}\text { Plant pathogen of } \\
\text { grains (rice seeds) }\end{array}$ & $\begin{array}{l}\text { Cottyn et al., } \\
\text { 2001; Jeong et } \\
\text { al., } 2003\end{array}$ \\
\hline Clavibacter michiganensis (1) & SI & $\mathrm{M}$ & Small white pustules & $(+)$ & $\begin{array}{l}\text { Plant pathogen of } \\
\text { tomato }\end{array}$ & $\begin{array}{l}\text { Davis et al., } \\
1984\end{array}$ \\
\hline Curtobacterium flaccumfaciens (2) & SI & B & $\begin{array}{l}\text { Dry wide white } \\
\text { lesions and wide } \\
\text { chlorotic lesions }\end{array}$ & $(+)$ & $\begin{array}{l}\text { Plant pathogen of } \\
\text { Phaseolus vulgaris, } \\
P \text {. coccineus, P. lu- } \\
\text { natus, Vigna angu- } \\
\text { laris, V. radiata and } \\
\text { V. mungo; soybeans, } \\
\text { peas, cowpeas and } \\
\text { Lablab purpureus. }\end{array}$ & $\begin{array}{l}\text { Schaad et al., } \\
2001 ; \text { http:// } \\
\text { www.eppo.org }\end{array}$ \\
\hline Cytophaga sp. (1) & SI & M & Wide chlorotic lesions & $(-)$ & $\begin{array}{l}\text { Various sources: } \\
\text { soil, pine litter } \\
\text { soils, fish, etc. }\end{array}$ & $\begin{array}{l}\text { Bernardet et al., } \\
1996\end{array}$ \\
\hline
\end{tabular}

${ }^{1}$ The survey consisted of eight sampling trials with 15-day interval between them. Bacteria were identified by using BIOLOG®. Number of bacterial strains in parentheses.

${ }^{2}$ Location of commercial (SI = Santa Isabel) and experimental (JD = Juana Díaz) onion fields in Puerto Rico.

'Onion cultivars sampled: $\mathrm{E}=$ 'Excalibur' and $\mathrm{M}=$ 'Mercedes'; $\mathrm{B}=$ occurs in both cultivars.

${ }^{4}$ Possible source of origin based on literature. 
TABLE 1. (CONTINUED) Bacterial strains isolated from onion (Allium cepa L.) foliar lesions in commercial and experimental field plots located at Juana Diaz and Santa Isabel, Puerto Rico.

\begin{tabular}{|c|c|c|c|c|c|c|}
\hline Bacterial Identification $^{1}$ & Location $^{2}$ & $\mathbf{C V}^{3}$ & Lesion type & $\begin{array}{l}\text { Gram } \\
\text { Stain }\end{array}$ & Possible Source $^{4}$ & References \\
\hline Enterobacter cloacae (2) & JD & $\mathrm{E}$ & $\begin{array}{l}\text { Ellipsoidal sunken } \\
\text { lesion with soft rot } \\
\text { and disruption of } \\
\text { tissue }\end{array}$ & $(-)$ & $\begin{array}{l}\text { Plant pathogen } \\
\text { causing bulb decay } \\
\text { and premature } \\
\text { leaf dieback of on- } \\
\text { ion, bacteriosis in } \\
\text { payaya fruits and } \\
\text { ginger roots. }\end{array}$ & $\begin{array}{l}\text { Zaid et al., } \\
2011 ; \text { Schroed- } \\
\text { er et al., 2009; } \\
\text { Nishijima et } \\
\text { al., } 1987 \text { and } \\
2004\end{array}$ \\
\hline Flavimonas oryzihabitans (1) & JD & M & $\begin{array}{l}\text { Ellipsoidal sunken } \\
\text { lesion with soft rot } \\
\text { and disruption of } \\
\text { tissue }\end{array}$ & $(-)$ & Rice seeds & $\begin{array}{l}\text { Kim et al. } \\
1998\end{array}$ \\
\hline Mannheimia haemolytica (1) & SI & $\mathrm{M}$ & Small white pustules & $(-)$ & $\begin{array}{l}\text { Goats, sheeps and } \\
\text { cattle pathogen }\end{array}$ & $\begin{array}{l}\text { Zecchinon et } \\
\text { al., } 2005\end{array}$ \\
\hline Pantoea agglomerans (4) & SI & B & $\begin{array}{l}\text { Small white pustules, } \\
\text { dry wide white lesions } \\
\text { and wide chlorotic le- } \\
\text { sions }\end{array}$ & $(-)$ & $\begin{array}{l}\text { Seed-borne in on- } \\
\text { ions; onion patho- } \\
\text { gen }\end{array}$ & $\begin{array}{l}\text { Alameda and } \\
\text { Rivera-Vargas, } \\
\text { 2010; Schwartz } \\
\text { and Mohan, } \\
1995\end{array}$ \\
\hline
\end{tabular}

${ }^{1}$ The survey consisted of eight sampling trials with 15-day interval between them. Bacteria were identified by using BIOLOG@. Number of bacterial strains in parentheses.

${ }^{2}$ Location of commercial (SI = Santa Isabel) and experimental (JD = Juana Díaz) onion fields in Puerto Rico.

${ }^{3}$ Onion cultivars sampled: $\mathrm{E}=$ 'Excalibur' and $\mathrm{M}=$ 'Mercedes'; $\mathrm{B}=$ occurs in both cultivars.

${ }^{4}$ Possible source of origin based on literature. 
TABLE 1. (CONTINUED) Bacterial strains isolated from onion (Allium cepa L.) foliar lesions in commercial and experimental field plots located at Juana Díaz and Santa Isabel, Puerto Rico.

\begin{tabular}{|c|c|c|c|c|c|c|}
\hline Bacterial Identification ${ }^{1}$ & Location $^{2}$ & $\mathbf{C V}^{3}$ & Lesion type & $\begin{array}{l}\text { Gram } \\
\text { Stain }\end{array}$ & Possible Source $^{4}$ & References \\
\hline Pantoea dispersa (5) & $\mathrm{SI} / \mathrm{JD}$ & B & $\begin{array}{l}\text { Ellipsoidal sunken } \\
\text { lesion with soft rot } \\
\text { and disruption of } \\
\text { tissue; round soft rot } \\
\text { lesions; and round } \\
\text { chlorotic spots }\end{array}$ & $(-)$ & $\begin{array}{l}\text { Seed-borne in } \\
\text { onions; onion } \\
\text { pathogen }\end{array}$ & $\begin{array}{l}\text { Alameda and } \\
\text { Rivera-Vargas, } \\
\text { 2010; Hattingh } \\
\text { and Walters, } \\
\text { 1981; Morales } \\
\text { et al., } 1994\end{array}$ \\
\hline Pantoea stewartii (1) & SI & $\mathrm{E}$ & $\begin{array}{l}\text { Sunken chlorotic le- } \\
\text { sion causing stran- } \\
\text { gled leaf }\end{array}$ & $(-)$ & Corn pathogen & $\begin{array}{l}\text { Block et al., } \\
\text { 1998; Schaad et } \\
\text { al., 2001 }\end{array}$ \\
\hline Pasteurella anatis (1) & SI & $\mathrm{M}$ & Wide chlorotic lesions & $(-)$ & Avian pathogen & $\begin{array}{l}\text { Christensen et } \\
\text { al., } 2003 \text {. }\end{array}$ \\
\hline Pasteurella bettyae (1) & SI & $\mathrm{M}$ & Small white pustules & $(-)$ & Human & $\begin{array}{l}\text { Gautier et al., } \\
2005\end{array}$ \\
\hline Pasteurella langaaensis (2) & SI & B & Small white pustules & $(-)$ & Birds & $\begin{array}{l}\text { Kehrenberg et } \\
\text { al., } 2001\end{array}$ \\
\hline Photobacterium damselae (1) & JD & $\mathrm{E}$ & $\begin{array}{l}\text { Ellipsoidal sunken le- } \\
\text { sion with soft rot and } \\
\text { disruption of tissue }\end{array}$ & $(-)$ & Fish & $\begin{array}{l}\text { Osorio et al., } \\
1999\end{array}$ \\
\hline Pseudomonas sp. (1) & SI & $\mathrm{E}$ & Small white pustules & $(-)$ & Plant pathogen & $\begin{array}{l}\text { Schaad et al., } \\
2001\end{array}$ \\
\hline Pseudomonas syringae pv. aptata (1) & JD & $\mathrm{M}$ & $\begin{array}{l}\text { Ellipsoidal sunken le- } \\
\text { sion with soft rot and } \\
\text { disruption of tissue }\end{array}$ & $(-)$ & Sugar beet & $\begin{array}{l}\text { Schaad et al., } \\
2001 .\end{array}$ \\
\hline
\end{tabular}

${ }^{1}$ The survey consisted of eight sampling trials with 15-day interval between them. Bacteria were identified by using BIOLOG®. Number of bacterial strains in parentheses.

${ }^{2}$ Location of commercial (SI = Santa Isabel) and experimental (JD = Juana Díaz) onion fields in Puerto Rico.

'Onion cultivars sampled: $\mathrm{E}=$ 'Excalibur' and $\mathrm{M}=$ 'Mercedes'; $\mathrm{B}=$ occurs in both cultivars.

${ }^{4}$ Possible source of origin based on literature. 
TABLE 1. (CONTINUED) Bacterial strains isolated from onion (Allium cepa L.) foliar lesions in commercial and experimental field plots located at Juana Diaz and Santa Isabel, Puerto Rico.

\begin{tabular}{|c|c|c|c|c|c|c|}
\hline Bacterial Identification $^{1}$ & Location $^{2}$ & $\mathbf{C V}^{3}$ & Lesion type & $\begin{array}{l}\text { Gram } \\
\text { Stain }\end{array}$ & Possible Source $^{4}$ & References \\
\hline Rhizobium radiobacter $(1)$ & JD & M & $\begin{array}{l}\text { Ellipsoidal sunken le- } \\
\text { sion with soft rot and } \\
\text { disruption of tissue }\end{array}$ & $(-)$ & $\begin{array}{l}\text { Pathogenic and } \\
\text { non-pathogenic } \\
\text { strains }\end{array}$ & $\begin{array}{l}\text { Young et al., } \\
2001\end{array}$ \\
\hline Serratia rubidae (4) & SI & B & $\begin{array}{l}\text { Small white pustules; } \\
\text { dry wide white lesions }\end{array}$ & $(-)$ & Bovine pathogen & $\begin{array}{l}\text { Todhunter et } \\
\text { al., } 1991\end{array}$ \\
\hline Sphingobacterium spiritivorum (1) & SI & $\mathrm{M}$ & $\begin{array}{l}\text { Small white pustules; } \\
\text { dry wide white lesions }\end{array}$ & $(-)$ & $\begin{array}{l}\text { Weeds, human } \\
\text { pathogen }\end{array}$ & $\begin{array}{l}\text { Sturz et al., } \\
2001 \text {; Mari- } \\
\text { nella, } 2002\end{array}$ \\
\hline Sphingomonas sanguinis (2) & SI & B & $\begin{array}{l}\text { Small white pus- } \\
\text { tules; sunken chlo- } \\
\text { rotic lesion causing } \\
\text { strangled leaf }\end{array}$ & $(-)$ & Plants surface & $\begin{array}{l}\text { Kim et al. } \\
1998\end{array}$ \\
\hline Xanthomonas sp. (2) & JD & $\mathrm{E}$ & $\begin{array}{l}\text { Ellipsoidal sunken } \\
\text { lesion with soft rot } \\
\text { and disruption of } \\
\text { tissue }\end{array}$ & $(-)$ & $\begin{array}{l}\text { Plant pathogen, } \\
\text { coffee endophyte }\end{array}$ & $\begin{array}{l}\text { Schwartz and } \\
\text { Mohan, 1995; } \\
\text { O'Garro and } \\
\text { Paulraj, 1997; } \\
\text { Schaad et al., } \\
2001\end{array}$ \\
\hline Xanthomonas - like (1) & SI & $\mathrm{E}$ & Wide chlorotic lesions & $(-)$ & Plant pathogen & $\begin{array}{l}\text { Schwartz and } \\
\text { Mohan, 1995; } \\
\text { O'Garro and } \\
\text { Paulraj, } 1997\end{array}$ \\
\hline Unknown (1) & SI & M & Round soft rot lesions & $(-)$ & - & - \\
\hline
\end{tabular}

${ }^{1}$ The survey consisted of eight sampling trials with 15-day interval between them. Bacteria were identified by using BIOLOG( $\mathrm{Number}$ of bacterial strains in parentheses.

${ }^{2}$ Location of commercial (SI = Santa Isabel) and experimental (JD = Juana Díaz) onion fields in Puerto Rico.

${ }^{3}$ Onion cultivars sampled: $\mathrm{E}=$ 'Excalibur' and $\mathrm{M}=$ 'Mercedes'; $\mathrm{B}=$ occurs in both cultivars.

${ }^{4}$ Possible source of origin based on literature. 


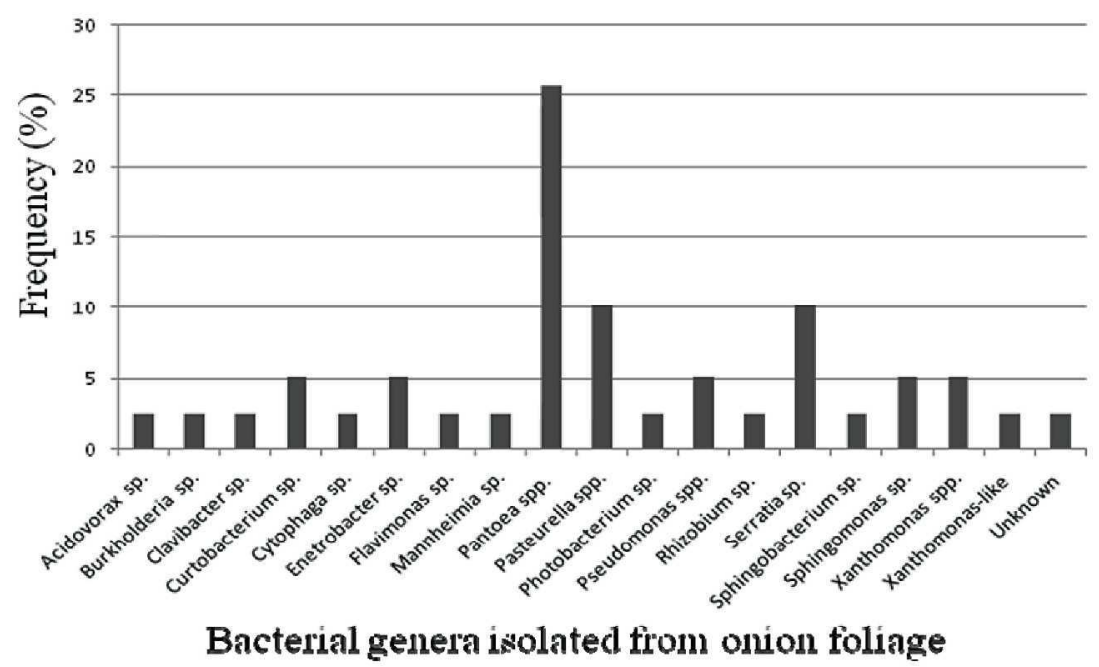

FigURE 2. Frequency (\%) of bacterial genera isolated from onion foliage.

ringae pathovar aptata, $R$. rhadiobacter and Xanthomonas sp. In addition, $P$. dispersa was isolated from round soft rot lesions, as well as an unknown bacteria species (Figure 1B). A diverse bacterial flora was isolated from small white pustules: Clavibacter michiganensis, $M$. haemolytica, $P$. agglomerans, $P$. bettyae, $P$. langaaensis, Pseudomonas spp., S. rubidae, and $S$. sanguinis (Figure 1C). These symptoms were further associated with Leveillula taurica, a powdery mildew of onion in the field (Feliciano and Rivera, 2006). Curtobacterium flaccumfaciens, Cytophaga sp., P. agglomerans, P. annatis, and a Xanthomonaslike strain were isolated from wide chlorotic lesions (Figure 1D). Four bacterial species, $C$. flaccumfaciens, $P$. agglomerans, $S$. rubidae and $S$. spiritivorum, were isolated from dry wide white lesions (Figure 1E). These symptoms have been associated with herbicide toxicity in Canada (Chaput, 1995). Pantoea sterwartii and S. sanguinis were the only species isolated from sunken chlorotic lesions causing strangling of the leaf (Figure 1F). Pantoea dispersa was the only strain obtained from chlorotic spots (Figure 1G).

\section{Pathogenicity tests conducted under field conditions}

Acidovorax avenae subsp. citrulli, B. glumae, $P$. agglomerans, $P$. dispersa, Pseudomonas sp., Xanthomonas sp., and a Xanthomonas-like strain were found pathogenic to onion tissues of both cultivars under field conditions as compared to controls (Table 2 and Figure 3). Pre- 
liminary reports of these findings have been published elsewhere (Calle-Bellido et al., 2006; Alameda and Rivera, 2010). Acidovorax avenae subsp. citrulli caused ellipsoidal sunken lesions with soft rot around the inoculation point in both cultivars; disruption of the tissues was observed seven days after inoculation (Table 2; Figure 3). Burkholderia glumae caused wide soft rot with sunken lesions and disruption of tissues around inoculation points. Symptoms were more severe in 'Mercedes' seven days after inoculation (Table 2; Figure 2). Pseudomonas sp. caused elongated lesions; a soft rot was more severe in 'Mercedes', disruption of tissues was observed seven days after inoculation (Table 2; Figure 2). Two strains of $P$. agglomerans were evaluated in this study; both caused small white spots with sunken tissue around inoculation points. Pantoea dispersa caused minute lesions with soft rot and disruption of tissues. Symptoms were more severe in 'Mercedes' than in 'Excalibur' (Table 2; Figure 2). Xanthomonas sp. produced wide ellipsoidal white sunken lesions. Coalescence of lesions and disruption of tissues were observed seven days after inoculation in both cultivars evaluated (Figure 2). The Xanthomonas-like strain caused slight soft rot around inoculation points in both cultivars evaluated (Table 2). Clavibacter michiganensis was not pathogenic; no lesions were observed in leaf tissue. Symptom development was not observed in the controls. Koch's postulates were fulfilled by re-isolation of the different bacterial strains inoculated. Burkholderia glumae was not re-isolated

TABLE 2. Symptoms observed in onion foliage of 'Excalibur' and 'Mercedes' during pathogenicity tests conducted under field conditions at the Agricultural Experiment Station, Juana Día, Puerto Rico.

Bacterial Strains

Acidovorax avenae subsp. citrulli

Burkholderia glumae

Clavibacter michiganensis

Pantoea agglomerans

Pantoea dispersa

Pseudomonas sp.

Xanthomonas sp.

Xanthomonas-like

\section{Symptoms observed in onion foliage}

Ellipsoidal sunken lesion with soft rot. Disruption of the tissues in both cultivars.

Wide soft rot with sunken lesions around inoculation points in both cultivars.

No symptoms were developed.

Small white spots with sunken tissue around inoculation points in both cultivars.

Soft rot. Abundant minute lesions in Mercedes' compared to those in 'Excalibur.'

Ellipsoidal soft rot lesion and disruption of the tissues in both cultivars.

Ellipsoidal white sunken lesions and soft rot in both cultivars. Disruption of the tissues.

Slight soft rot around inoculation point and wide chlorotic lesions in both cultivars. Disruption of the tissues. 
'Excalibur'

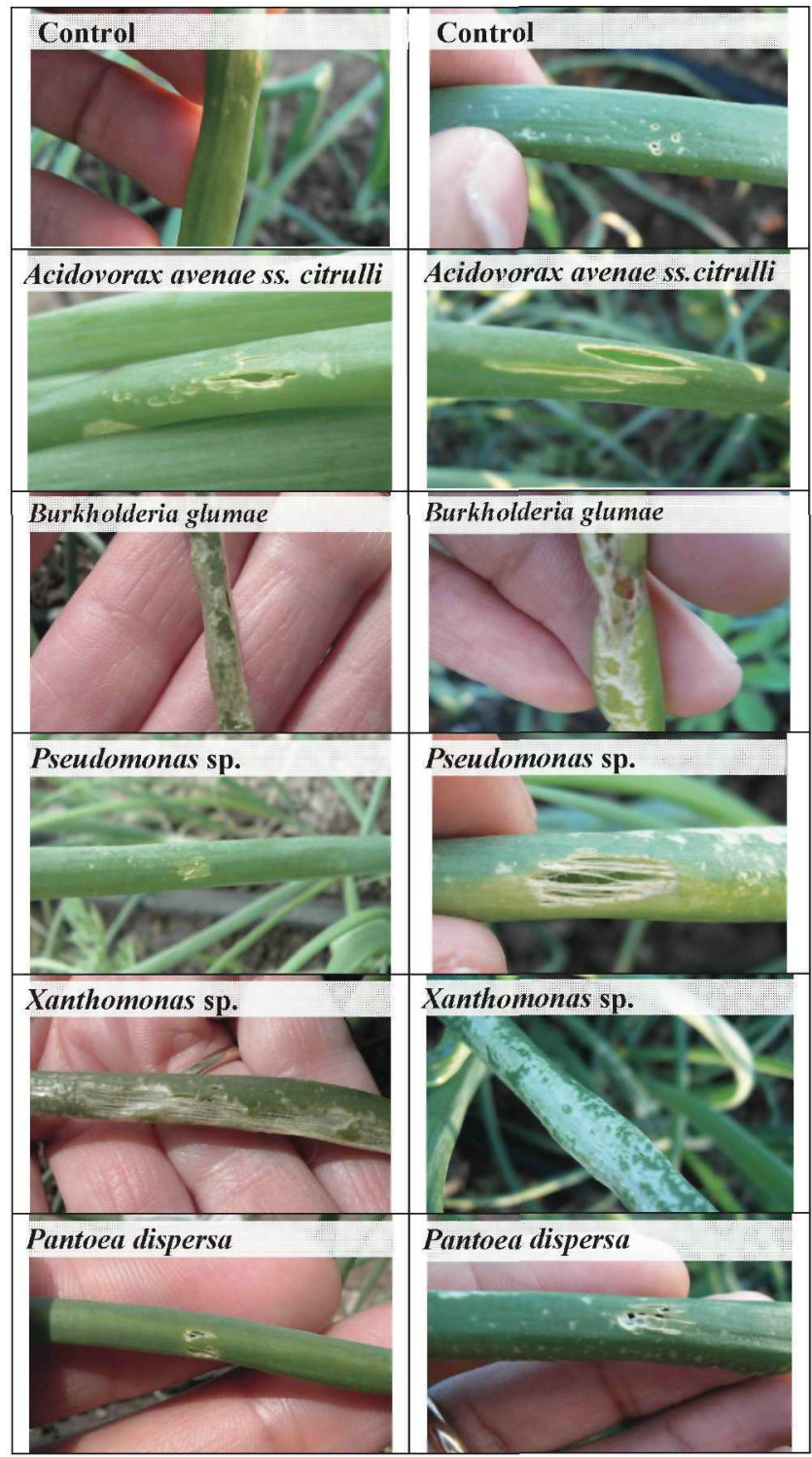

FIGURE 3. Symptoms observed during pathogenicity tests conducted with bacterial strains in onion foliage of 'Mercedes' and 'Excalibur' in plots located at Juana Díaz, Puerto Rico. Control and plants inoculated with Clavibacter michiganensis did not show symptoms. 
from infected tissues, thus requiring further investigation. Identity of re-isolated bacteria was corroborated using BIOLOG ${ }^{\circledR}$.

\section{DISCUSSION}

Enterobacteriaceae was predominant on onion foliage (up to $41 \%$ ), which agrees with findings in other crops (Cottyn et al., 2001). Pantoea agglomerans (synom. $E$. herbicola) has been reported to be causing stalk and leaf necrosis in onions in South Africa (Hattingh and Walters, 1981). Two strains of Pantoea agglomerans were evaluated in this study; both caused small white spots with sunken tissue around inoculation points. Studies of bacteria associated with onion seeds in Puerto Rico have shown that $P$. agglomerans was the most common bacteria isolated from seed tissues of 'Mercedes'. Pantoea dispersa was also found in seeds but less frequently (Alameda and Rivera-Vargas, 2010). In our studies, $P$. dispersa was found in both commercial and experimental plots causing minute lesions on both cultivars during pathogenicity tests. It was reported from onion seeds in Cuba (Morales et al., 1994). Pantoea dispersa and $P$. agglomerans on onion foliage might be related to its potential to develop an epiphytic population. Even though superficial disinfection of leaf tissues was performed, bacteria invading natural openings, such as the stomatal pore, most probably were not totally removed from tissues (Sabaratnam and Beathie, 2003; Rosenblueth and Martínez-Romero, 2006). Another member of the family Enterobacteriaceae, E. cloacae, has been reported as an onion pathogen causing premature leaf dieback and bulb soft rot (Zaid et al., 2011). In Puerto Rico, this species has frequently (19\%) been found in seeds of 'Excalibur', but its pathogenic potential was not evaluated during our studies (Alameda and Rivera-Vargas, 2010).

In the field, onion might build populations of $A$. avenae subsp. citrulli. This species was detected in experimental plots at Juana Díaz and has not been reported in Puerto Rico to be associated with onions. In our experiments, this species has caused ellipsoidal sunken lesions with soft rot around the inoculation point, with disruption of onion leaf tissue. It is important to mention that our experimental onion plots were located close to cucurbit plots. Acidovorax avenae subsp. citrulli, causes cucurbit fruit rot, especially in honeydew, and fruit blotch in watermelons (Isakeit et al., 1997; Somodi et al., 1991).

Gram positive bacteria such as C. michiganensis and C. flaccumfaciens were associated with onion commercial plots located in Santa Isabel. Both species cause important diseases in other crops, such as beans, tomatoes and corn (Schaad et al., 2001). These crops are extensively cultivated in the surroundings of the commercial plots studied, 
which might explain their presence on onion foliage. As expected, during pathogenicity tests Clavibacter michiganensis was not pathogenic to onion leaf tissues.

Pseudomonas spp. and Xanthomonas spp. are important pathogens of a wide range of plants of economic importance and have been previously reported in Puerto Rico (Cortés-Monllor, 1992 and 1993; Zapata, 1995; Schaad et al., 2001). However, none of these have been reported in onions, with the exception of Burkholderia cepacia (syn. Pseudomonas cepacia) causing sour skin of onions (Campo and Zapata, 1996). Among the pseudomonads, Pseudomonas viridiflava has been reported in Georgia causing oval water-soaked lesions with the subsequent development of a black stripe in onions (Gitaitis et al., 1997). Stripe symptoms were not observed in the field during our studies. Xanthomonas axonopodis pv. alli is an important pathogen of onion causing bacterial blight in Hawaii and Colorado (Álvarez et al., 1978; Gent et al., 2005). In the literature, symptoms are described as small water-soaked spots that enlarge into chlorotic lesions; collapse of the leaf occurrs at the point of initial infection. Infected onion seeds have elsewhere been pointed out as the mechanism of dissemination and origin of the disease (Robène-Soustrade et al., 2010). In our studies Xanthomonas sp. was found associated with onion foliage causing soft rot, but was not isolated from onion seeds in studies conducted in Puerto Rico (Alameda and Rivera-Vargas, 2010). During the pathogenicity tests Xanthomonas sp. produced ellipsoidal white sunken lesions and soft rots. Also a Xanthomonas-like strain was found associated with wide chlorotic lesions, causing slight soft rot in both cultivars. Further studies are needed to characterize pathogenic pseudomonads and xanthomonads present on onion foliage in the island.

Some bacteria can be latent pathogens, and infections may develop under certain environmental conditions. Precipitation and relative humidity $(\mathrm{RH})$ are important variables that should be taken into consideration in bacterial epiphytotics because both variables increase water moisture on foliage tissues conducive to bacteria multiplication and dissemination in the field. During this investigation, temperature was stable, ranging from 24 to $26^{\circ} \mathrm{C}$ with a mean of $24.87^{\circ} \mathrm{C}$. Precipitation was low, only two rainy days with 4 and $8 \mathrm{~mm} / \mathrm{m}^{2}$ of rain $\left(1.5 \mathrm{~mm} / \mathrm{m}^{2}\right.$ average); $\mathrm{RH}$ ranged from 68.4 to $88.4 \%$ with an average of $78 \%$. High $\mathrm{RH}(>95 \%)$ promotes bacterial entry into the leaf and its multiplication in tissues (Sabaratnam and Beattie, 2003). Heavy rains have been associated with increase of $P$. syringae $\mathrm{pv}$. syringae and $P$. agglomerans populations on bean leaves (Sabaratnam and Beattie, 2003).

Besides the bacteria role as plant pathogens, bacteria population in plant tissues has been associated with other roles, such as promo- 
tion of plant growth, increase in disease resistance, protection against microbial pathogens and pests (Rosenblueth and Martínez-Romero, 2006). In addition, some bacterial strains such as $M$. haemolytica, $P$. agglomerans, $P$. anatis, $P$. bettyae, $P$. langaaensis, $P$. damselae and $S$. rubidae identified in our study are of clinical or veterinary interest (Christensen et al, 2003; de Champs et al., 2000; Gautier et al., 2005; Kehrenberg et al., 2001; Marinella, 2002; Osorio et al., 1999; Todhunter et al., 1991; Zecchinon et al., 2005).

Even though these studies have provided substantial information on the heterogeneity of bacterial populations in onion foliage, further studies in different onion production seasons are necessary to validate our findings. Comprehensive studies that include different approaches to bacterial identification, such as fatty acid analysis, DNA sequence analysis, in addition to BIOLOG® and phenotypic characterization, are recommended to assess the composition of bacterial communities on onion leaves. This is the first survey of bacterial diversity associated with onion foliage in Puerto Rico. The role of non-phytopathogenic bacteria associated with the life cycle of onion under field conditions remains unknown.

\section{LITERATURE CITED}

Alameda, M. and L. I. Rivera-Vargas, 2010. Seed-borne endophytic and pathogenic bacteria isolated from onion in Puerto Rico. J. Agric. Univ. P.R. 94(3-4): 289-291.

Álvarez, A. M., I. W. Buddenhagen, E. S. Buddenhagenandand and H. Y. Domen, 1978. Bacterial blight of onion, a new disease caused by Xanthomonas sp. Phytopathology 68: 1132-1136.

Bernardet, J. F., P. Segers, M. Vancanneyt, F. Berthe, K. Kersters and P. Vandamme, 1996. Cutting a Gordian Knot: Emended Classification and Description of the Genus Flavobacterium, Emended Description of the Family Flavobacteriaceae, and Proposal of Flavobacterium hydatis nom. nov. (Basonym. Cytophaga aquatilis Strohl and Tait 1978). Int. J. Syst. Bacteriol. 46(1): 128-148.

Block, C. C., J. H. Hill and D. C. McGee, 1998. Seed transmission of Pantoea stewartii in field and sweet corn. Plant Dis. 82: 775-780.

Bochner, B. R., 1989. Sleuthing out bacterial identities. Nature 339:157-158.

Campo, R. O. and M. Zapata, 1996. Patogenicidad de Burkholderia cepacia (Pseudomonas cepacia) en cuatro genotipos de cebolla (Allium spp.). J. Agric. Univ. P.R. 80 (3-4): 123-134.

Calle-Bellido, J., M. Alameda and L. I. Rivera-Vargas, 2006. Foliar bacteria associated to onions in Puerto Rico. Phytopathology 96(6S): S162. (Abstract)

Chaput, J., 1995. Identification of Diseases and Disorders of Onions Fact Sheet 95063. Ontario Ministry of Agriculture, Food and Rural Affairs. Ontario, Canada. http://www.omafra.gov.on.ca/english/crops/facts/95-063.htm

Christensen, H., M. Bisgaard, A. M. Bojesen, R. Mutters and J. E. Olsen, 2003. Genetic relationships among strains of biovars of avian isolates classified as 'Pasteurella haemolytica', 'Actinobacillus salpingitidis'or Pasteurella anatis with 
proposal of Gallibacterium anatis gen. nov., comb. nov. and description of additional genomospecies within Gallibacterium gen. nov. International Journal of Systematic and Evolutionary Microbiology 53: 275-287.

Cortés-Monllor, A., 1992. Diseases associated with pathovars of the Xanthomonas campestris group in Puerto Rico. J. Agric. Univ. P.R. 76(3-4): 187-207.

Cortés-Monllor, A., 1993. Diseases caused by Pseudomonas spp. in some cultivars in Puerto Rico - an updating. J. Agric. Univ. P.R. 77(3-4): 207-227.

Cottyn, B., E. Regalado, B. Lanoot, M. De Cleene, T. W. Mewand and J. Swings, 2001. Bacterial populations associated with rice seed in the tropical environment. Phytopathology 91: 282-292.

Davis, M. J., A. G. Gillaspie Jr., A. K. Vidaver and R. W. Harris, 1984. Clavibacter: a new genus containing some phytopathogenic Coryneform bacteria, including Clavibacter xyli subsp. xyli sp. nov., subsp. nov. \& Clavibacter xyli subsp. cynodontis subsp. nov., pathogens that cause Ratoon stunting disease of sugarcane and Bermudagrass stunting disease. International Journal of Systemic Bacteriology 34: 107-117.

De Champs, C., S. Le Seaux, J. J. Dubost, S. Boisgard, B. Sauvezie and J. Sirot, 2000. Isolation of Pantoea agglomerans in two cases of septic monoarthritis after plant thorn and wood sliver injuries. J. Clin. Microbiol. 38(1): 460-461.

Department of Agriculture of Puerto Rico, 2010. Agricultural Annual Gross Income, revised data 2008-2009 and preliminary data 2009-2010. Commonwealth of Puerto Rico, San Juan, PR.

EPPO quarantine pest, 2010. http://www.eppo.org/QUARANTINE/bacteria/Curtobacterium_flaccumfaciens/CORBFL_ds.pdf

FAOSTAT, 2010. http://faostat.fao.org.

Feliciano-Rivera, M. and L. I. Rivera-Vargas, 2006. First report of powdery mildew of onion (Allium cepa L.) caused by Leveillula taurica (Lev.) Arn. in Puerto Rico. Proc. Caribbean Food Crops Society 42(2): 188-192.

Gautier, A. L., D. Dubois, F. Escande, J. L. Avril, P. Trieu-Cuot and O. Gaillot, 2005. Rapid and accurate identification of human isolates of Pasteurella and related species by sequencing the sodA gene. J. Clin. Microbiol. 43(5): 2307-2314.

Gent, D. H., J. M. Langand and H. F. Schwartz, 2005. Epiphytic survival of Xanthomonas axonopodis pv. allii and $X$. axonopodis pv. phaseoli on leguminous hosts and onion. Plant Dis. 89: 558-564.

Gitaitis, R., D. Sumner, D. Gay, D. Smittle, G. McDonald, B. Maw, W. C. Johnson III, B. Tollner and Y. Hung, 1997. Bacterial streak and bulb rot of onion: I. A diagnostic medium for the semiselective isolation and enumeration of $P$ seudomonas viridiflava. Plant Dis. 81: 897-900.

Gitaitis, R. D., R. R. Walcott, M. L. Wells, J. C. Diaz-Perez and F. H. Sanders, 2003. Transmission of Pantoea ananatis, causal agent of center rot of onion, by tobacco thrips, Frankliniella fusca. Plant Dis. 87: 675-678.

Hattingh, M. J. and D. F. Walters, 1981. Stalk and leaf necrosis of onion caused by Erwinia herbicola. Plant Dis. 65: 615-618.

Isakeit, T., M. C. Black, L. W. Barnes and J. B. Jones, 1997. First report of infection of honeydew with Acidovorax avenae subsp. citrulli. Plant Dis. 81: 694.

Jeong, Y., J. Kim, S. Kim, Y. Kang, T. Nagamatsu and I. Hwang, 2003. Toxoflavin produced by Burkholderia glumae causing rice grain rot is responsible for inducing bacterial wilt in many field crops. Plant Dis. 87: 890-895.

Kehrenberg, C., G. Schulze-Tanzil, J. L. Martel, E. Chaslus-Dancla and S. Schwarz, 2001. Antimicrobial resistance in Pasteurella and Mannheimia: epidemiology and genetic basis. Vet. Res. 32: 323-339. 
Kim, H., M. Nishiyama, T. Kunito, K. Senoo, K. Kawahara, K. Murakami and H. Oyaizu, 1998. High population of Sphingomonas species on plant surface. J. Appl. Microbiol. 85 (4): 731-736.

Marinella, M. A., 2002. Cellulitis and sepsis due to Sphingomonas. JAMA 288(16): 1985.

Morales, N., J. Vietinghoff, M. de los A. Peres, N. Rodriguez de la Rosa, A. Moreno, I. Cuello and D. Seidel, 1994. Erwinia herbicola (Lohnis) Dye a new pathogen of onion seed production (Allium cepa L.) in Cuba. Arch. Phytopathol. Plant Prot. 29: 29-40.

Neto, J. R., V. A. Malavolta, Jr., M. A. Cardelli, and C. Sinigaglia. 1987.Ocorrencia de uma nova doenc, a bacteriana em cebola, no estado de Sao Paulo. Summa Phytopathol. 13:10.

Nishijima, K. A., A. M. Álvarez, P. R. Hepperly, M. H. Shintaku, L. M. Keith, D. M. Sato, B. C. Bushe, J. W. Armstrong and F. T. Zee, 2004. Association of Enterobacter cloacae with rhizome rot of edible ginger in Hawaii. Plant Dis. 88: 1318-1327.

Nishijima, K., H. Melvin Couey and A. M. Álvarez, 1987. Internal yellowing, a bacterial disease of papaya fruits caused by Enterobacter cloacae. Plant Dis. 71: 1029-1034.

O'Garro, L. W. and L. P. Paulraj, 1997. Onion leaf blight caused by Xanthomonas campestris alternative host and resistant onion genotypes. Plant Dis. 81: 978972.

Osorio, C. R., M. D. Collins, A. E. Toranzo, J. L. Barja and J. L. Romalde, 1999. 16S rRNA Gene Sequence Analysis of Photobacterium damselae and Nested PCR Method for Rapid Detection of the Causative Agent of Fish Pasteurellosis. Appl. Environ. Microbiol. 65(7): 2942-2946.

Robène-Soustrade, I., D. Legrand, L. Gagnevin, F. Chiroleu, A. Laurent and O. Pruvost, 2010. Multiplex nested PCR for Detection of Xanthomonas axonopodis pv. allii from onion seeds. App. Environ. Microbiol. 76(9): 2697-2703.

Rosenblueth, M. and E. Martínez-Romero, 2006. Bacterial endophytes and their interactions with hosts. MPMI. 19(8): 827-837.

Sabaratnam, S. and G. A. Beattie, 2003. Differences between Pseudomonas syringae pv. syringae B728a and Pantoea agglomerans BRT98 in epiphytic and endophytic colonization of leaves. Appl. Environ. Microbiol. 69: 1220-1228.

Schaad, N. W., J. B. Jones and W. Chun, 2001. Plant pathogenic bacteria. Third edition. APS Press. Saint Paul, Minn. 373 pp.

Schroeder, B. K., L. J. du Toit and H. F. Schwartz, 2009. First report of Enterobacter cloacae causing onion bulb rot in the Columbia Basin of Washington State. Plant Dis. 93(3): 323 .

Schwartz, H. F. and D. H. Gent, 2005. Xanthomonas Leaf Blight of Onion. Colorado State University Extension Fact Sheet no. 2.951. http://www.ext.colostate.edu/ pubs/garden/02951.html

Schwartz, H. F. and K. Mohan, 1995. Compendium of onion and garlic disease. Academic Press. San Diego, California. 54 pp.

Serfontein, J. J., 2001. Xanthomonas blight of onion in South Africa. Plant Dis. 85: 442.

Snowdon, A. L., 2002. A colour atlas of post-harvest diseases and disorders of fruits and vegetables. Volume 2: Vegetables. Manson Publishing Ltd., UK. 416 pp.

Somodi, G. C., J. B. Jones, D. L. Hopkins, R. E. Stall, T. A. Kucharek, N. C. Hodge and J. C. Watterson, 1991. Occurrence of a bacterial watermelon fruit blotch in Florida. Plant Dis. 75: 1053-1056. 
Sturz, A. V., B. G. Matheson, W. Arsenault, J. Kimpinski and B. R. Christie, 2001. Weeds as a source of plant growth promoting rhizobacteria in agricultural soils. Can. J. Microbiol. 47: 1013-1042.

Todhunter, D. A., K. L. Smith and J. S. Hogan, 1991. Serratia species isolated from bovine intramammary infections. J. Dairy Sci. 74(6): 1860-1865.

Young, J. M., L. D. Kuykendall, E. Martínez-Romero, A. Kerr and H. Sawada, 2001. A revision of Rhizobium Frank 1889, with an emended description of the genus, and the inclusion of all species of Agrobacterium Conn 1942 and Allorhizobium undicola de Lajudie et al. 1998 as new combinations: Rhizobium radiobacter, R. rhizogenes, R. rubi, R. undicola and R. vitis. Int. J. Syst. Evo. Microbiol. 51: 89-103.

Zaid, A. M., J. M. Bonasera and S. V. Beer, 2011. First report of Enterobacter bulb decay of onions caused by Enterobacter cloacae in New York. Plant Dis. 95(12): 1581.

Zapata, M., 1995. Bacterial spot on pepper caused by Xanthomonas campestris pv. vesicatoria, Race 2, from the south coast of Puerto Rico. J. Agric. Univ. P.R. 79(1-2): 43-50.

Zecchinon, L., T. Fett and D. Desmecht, 2005. How Mannheimia haemolytica defeats host defense through a kiss of death mechanism. Vet. Res. 36: 133-156. 
